\title{
Occupational Hazards to Doctors: Types, Distribution and Outcomes
}

\author{
Muhammad Umer Farooq ${ }^{1}$, Abbas Iqbal', Muhammad Tariq Shah ${ }^{1}$, Shahab Khan $^{2}$, Farhan Ullah, \\ Dawood Misbah1, Salma Shazia ${ }^{3}$, Muhammad Fayaz ${ }^{4}$.
}

\begin{abstract}
Background: The different types of hazards to which doctors are exposed in the hospitals need to be identified and eradicated. Objective: To study the awareness among doctors about the occupational hazards and the preventive measures that are taken.

Materials and Methods: The sample size was 200, selected by convenient non-probability technique. The study was conducted in Ayub Teaching Hospital, Abbottabad from $2^{\text {nd }}$ March 2019 to 3rd June 2020. Data was collected via questionnaires and then analyzed by using Statistical Package for Social Sciences 21. House Officers, Post graduate residents, and Trainee Registrars were included in the study.

Results: Most frequent hazard recorded was needle prick injury (52.5\%), followed by workload/stress/exhaustion (42.5\%). Study also showed that only half of doctors $(52.3 \%)$ were using preventive measures of different kinds like gloves, masks, standard operating procedures etc., rest $(47.7 \%)$ didn't use them. Almost half $(48.1 \%)$ of the doctors didn't report the hazards to the administration and even if they did, proper response was not given to address their problem.

Conclusion: Most common occupational hazards were found to be needle prick injury and exhaustion, and they were more prevalent among the doctors of surgery department. Consequently, doctors aren't able to perform their duties properly. Moreover, the hazards remained unreported both from doctors' and hospital administration's side.
\end{abstract}

Keywords: Hazards, Injuries, Awareness

This article may be cited as: Farooq MU,Iqbal A, Shah MT, Khan S, Farhan U, Misbah D, et al. Occupational Hazards to Doctors: Types, Distribution and Outcomes. J Saidu Med Coll Swat 2021;11(4):200-5.DOI:https://doi.org/10.52206/jsmc.2021.11.4.679

\section{INTRODUCTION}

Chemical, physical, biological and psychological are different types of hazards faced by workers in an occupation environment. ${ }^{1}$ Healthcare professional's amount to about 59 million which is $12 \%$ of the total working population worldwide, thus the study of their occupational hazards is important. $^{2}$

The risk of health of doctors is disregarded due to the assumption that for them, patients come before themselves. In 2014/15, the health of an estimated 30,000 health care workers in the UK was affected badly by their work. ${ }^{3}$ Most prevalent $(59 \%)$ were mental disorders, musculoskeletal (28\%) and dermatological diseases (5\%). Workrelated musculoskeletal disorders (WMSDs) can be defined as regional impairments of the tendons, muscles, joints and nerves that are associated with work-related mechanical injury; frequent of which are neck, back, shoulder, limbs, wrist and facial pain, most of which are multifactorial. ${ }^{4,5}$

1. Department of Medicine, Ayub Teaching Hospital, Abbottabad.

2. Department of Surgery, Khyber Teaching Hospital, Peshawar.

3. Department of Forensic Medicine, Ayub Medical College, Abbottabad.

4. Department of Medicine, Hayatabad Medical Complex, Peshawar.

Correspondence: Dr. Abbas Iqbal

MBBS House Officer, Department of Medicine,

Ayub Teaching Hospital, Abbottabad, KP, Pakistan.

E-mail: abbasiqbal0606@gmail.com
Needle stick injuries (NSIs) as defined by the United States National Institute of Occupational Safety and Health are injuries caused by needles, which can be blood collection needles, intravenous (IV) stylets, hypodermic needles, and needles used in IV delivery systems. The use of needles in the healthcare setup exposes professional to a wide range of infectious diseases. ${ }^{6,7}$

This study aims to find out the prevalence, demographics and distribution of occupational hazards to doctors working in the Ayub Teaching Hospital Abbottabad and the safety precautions taken by doctors in this regards. This will benefit our medical and paramedical professionals by increasing awareness of the current ground realities and help in formulating occupational health safety policies that will improve the working conditions and wellbeing of doctors not only in Abbottabad but also in the country as a whole.

\section{MATERIALS AND METHODS}

A cross-sectional study was carried out in Ayub teaching Hospital, Abbottabad from $2^{\text {nd }}$ March, 2019 to $3^{\text {rd }}$ June, 2020. A sample of 200 doctors was selected by convenient non-probability technique. The sample size was calculated using Cochran's formula; the approximate number of employees in Ayub teaching hospital being 850, at prevalence of $50 \%$, confidence interval $95 \%$ and a precision of $6.06 \%$. The number of questionnaires equaled the number of responses at $200 .^{7}$ Data 
collection tool was a questionnaire that was validated from two experts and its reliability was adjusted and then analyzed using SPSS.

Inclusion Criteria: The inclusion criterion was such that data was taken from House Officers, Post graduate residents, and Trainee Registrars after written informed consent and ensuring the confidentiality of their data and that the data would be purely used for research purposes.

Exclusion Criteria: Participants disagreeing to consent were excluded from the study. There were no quantitative variables. Qualitative variables were presented as frequency and percentage in the form of tables. No test of significance was applied

Ethical Approval and Review: The ethical consent (ethical review certificate) was obtained from the institute's ethical committee and review board on $20^{\text {th }}$ February 2019. The research had been reviewed by the ethical committee after the completion of study and was approved for the purpose of publication.

\section{Operational Definition:-}

Hazard: It is a potential source of harm.

Occupational Hazard: A risk accepted as a consequence of a particular occupation, like; needle prick injuries, workload, stress, exhaustion, chemical injuries, physical and mechanical injuries, nosocomial infections, physical and verbal abuse etc.

\section{RESULTS}

Majority of the participants were male. Only men had the knowledge of occupational hazards. Most but not all of the subjects had taken the preventive measures and a third of the subjects declared their working environment as not satisfactory towards providing adequate patient care. About half of the subjects informed the concerned authorities in an event of occupational hazards and declared the effort of working environment adequate for patient care. Not all requests to concerned authorities were answered.

Majority of the doctors in the study worked more than 60 hours a week (40.5\%) followed by $45-50$ hours a week (25.5\%). Only $12.5 \%$ were working for 55-60 hours per week. With respect to designation, $62 \%$ of our study sample were residents, $34 \%$ were house officers and $4 \%$ were Trainee registrars.
The highest prevalence of hazards was that of needle prick injuries $(52.5 \%)$ followed by exhaustion $(42.5 \%)$ while the lowest were that of physical and verbal abuse by patients, nosocomial infections and workplace bullying. Wearing Gloves was the most frequent type of preventive measure taken, it was followed by sanitizers use and face masks wearing. The least frequent precautions were radiation protection and limiting work hours.

The major reason for not taking any safety precaution as pointed out by $42 \%$ of the respondents was lack of facilities in hospital, whereas $7 \%$ did not consider taking precautions important.

Doctor were mostly from surgical $(49 \%)$ and medical $(30 \%)$ specialty and most of them were 'self-taught' about occupational hazards followed by 'Short-term courses'.

\section{Table No.1: Information about participants} and awareness about hazards.

\begin{tabular}{|c|c|c|c|}
\hline S.No & Parameter & Yes & No \\
\hline 1 & Gender & M-166 (83\%) & F-34 $(17 \%)$ \\
\hline 2 & Knowledge & $100 \%$ & $0 \%$ \\
\hline 3 & Exposure & $165(82 \%)$ & $35(18 \%)$ \\
\hline 4 & Repeated Exposure & $80 \%$ & $20 \%$ \\
\hline 5 & Taking Preventive Measures & $151(75.5 \%)$ & $49(24.5 \%)$ \\
\hline 6 & Working Environment & $\begin{array}{c}67 \% \\
\text { (Satisfactory) }\end{array}$ & $34 \%$ (Poor) \\
\hline 7 & $\begin{array}{l}\text { Effort of working environment } \\
\text { for providing proper care to } \\
\text { Patient }\end{array}$ & $58 \%$ & $42 \%$ \\
\hline 8 & $\begin{array}{l}\text { Informing Concerned } \\
\text { Authorities }\end{array}$ & $52 \%$ & $48 \%$ \\
\hline 9 & $\begin{array}{l}\text { Response of Concerned } \\
\text { Authorities }\end{array}$ & $78 \%$ & $22 \%$ \\
\hline 10 & Weekly Working Hours & $\begin{array}{l}<60 \text { hours } \\
55-60 \text { hours } \\
50-55 \text { hours } \\
45-50 \text { hours }\end{array}$ & $\begin{array}{l}81(40.5 \%) \\
25(12.5 \%) \\
43(21.5 \%) \\
51(25.5 \%)\end{array}$ \\
\hline 11 & Designation of participants & \begin{tabular}{|c|} 
House officer \\
Trainee \\
Registrar \\
Post Graduate \\
Resident
\end{tabular} & $\begin{array}{c}68(34 \%) \\
8(4 \%) \\
124(62 \%)\end{array}$ \\
\hline
\end{tabular}


Table No. 2: Hazards and Preventive measures.

\begin{tabular}{|c|c|c|c|c|c|c|c|c|}
\hline Parameter & \multicolumn{8}{|c|}{ Results } \\
\hline \multirow{3}{*}{$\begin{array}{c}\text { Types of } \\
\text { preventive } \\
\text { measures } \\
\text { taken }\end{array}$} & \multicolumn{8}{|c|}{ Response } \\
\hline & $\begin{array}{l}\text { Wearing } \\
\text { Gloves }\end{array}$ & $\begin{array}{c}\text { Wearing } \\
\text { Masks }\end{array}$ & $\begin{array}{c}\text { Using } \\
\text { Standard } \\
\text { Operative } \\
\text { Procedures } \\
\end{array}$ & $\begin{array}{c}\text { Limiting } \\
\text { work } \\
\text { hours }\end{array}$ & $\begin{array}{l}\text { Radiation } \\
\text { Protection }\end{array}$ & $\begin{array}{l}\text { Proper } \\
\text { Posture }\end{array}$ & $\begin{array}{l}\text { Sanitizer } \\
\text { Use }\end{array}$ & $\begin{array}{c}\text { Reporting } \\
\text { to } \\
\text { Authorities }\end{array}$ \\
\hline & 29 & 16 & 9 & 5 & 2 & 12 & 18 & 9 \\
\hline \multirow{3}{*}{$\begin{array}{c}\text { Types } \\
\text { of } \\
\text { Hazards }\end{array}$} & \multicolumn{8}{|c|}{ Response } \\
\hline & $\begin{array}{c}\text { Physical } \\
\text { or verbal } \\
\text { abuse by } \\
\text { patients }\end{array}$ & $\begin{array}{c}\text { Workplace } \\
\text { Bullying }\end{array}$ & $\begin{array}{l}\text { Depression } \\
\text { and } \\
\text { Anxiety }\end{array}$ & $\begin{array}{l}\text { Needle } \\
\text { Prick }\end{array}$ & $\begin{array}{c}\text { Nosocomial } \\
\text { Infections }\end{array}$ & $\begin{array}{l}\text { Physical } \\
\text { Injuries }\end{array}$ & $\begin{array}{c}\text { Chemical } \\
\text { Injuries }\end{array}$ & Exhaustion \\
\hline & $51(25.5 \%)$ & $50(25 \%)$ & $60(30 \%)$ & $105(52.5 \%)$ & $51(25.5 \%)$ & $57(28.5 \%)$ & $67(33.5 \%)$ & $85(42.5 \%)$ \\
\hline \multirow{3}{*}{$\begin{array}{c}\text { Reason } \\
\text { for not } \\
\text { taking any } \\
\text { preventive } \\
\text { measure }\end{array}$} & \multicolumn{8}{|c|}{ Response } \\
\hline & \multicolumn{3}{|c|}{ Lack of facilities in hospital } & $\begin{array}{l}\text { Lack of } \\
\text { time }\end{array}$ & $\begin{array}{c}\text { Lack of } \\
\text { awareness }\end{array}$ & $\begin{array}{c}\text { Could not } \\
\text { afford any } \\
\text { yourself }\end{array}$ & \multicolumn{2}{|c|}{$\begin{array}{l}\text { Don't consider } \\
\text { important }\end{array}$} \\
\hline & \multicolumn{3}{|c|}{$42 \%$} & $23 \%$ & $14 \%$ & $14 \%$ & \multicolumn{2}{|c|}{$7 \%$} \\
\hline
\end{tabular}

Table No. 3: Specialty distribution and Mode of education.

\begin{tabular}{|c|c|c|c|c|c|c|}
\hline Parameter & \multicolumn{7}{|c|}{ Results } \\
\hline \multirow{3}{*}{ Specialty } & Surgical & Medical & $\begin{array}{c}\text { Obstetrics } \\
\& \\
\text { Gynaecology }\end{array}$ & Orthopedic & Otolaryngologist & Paediatrics \\
\cline { 2 - 7 } & $97(49 \%)$ & $59(30 \%)$ & $16(8 \%)$ & $11(6 \%)$ & $9(5 \%)$ & $8(4 \%)$ \\
\hline \multirow{3}{*}{\begin{tabular}{c} 
Mode of \\
\cline { 2 - 7 }
\end{tabular}} & $\begin{array}{c}\text { Seniors } \\
\text { advice }\end{array}$ & Self-taught & $\begin{array}{c}\text { Taking } \\
\text { Seminars }\end{array}$ & $\begin{array}{c}\text { Short term } \\
\text { Courses }\end{array}$ & $\begin{array}{c}\text { On job } \\
\text { training }\end{array}$ & Diploma \\
\cline { 2 - 7 } & $25(12.5 \%)$ & $76(38 \%)$ & $26(13 \%)$ & $40(20 \%)$ & $24(12 \%)$ & $9(4.5 \%)$ \\
\cline { 2 - 7 }
\end{tabular}

\section{DISCUSSION}

Medical professionals are faced with many stressors. This study was conducted to focus on the hazards to which doctors were exposed, their effects and the awareness of the doctors. Sample size was 200 (166 males and 34 females). Study was carried out on doctors with 1-5 years' experience including House Officers, Postgraduate residents and Trainee Registrars, using structured questionnaires.
Our study showed that awareness about Occupational Hazards is significantly high $(100 \%)$. Out of the 200 people questioned, 165 $(82.5 \%)$ were exposed to at least one of the many hazards. Among the hazards, the most frequent came out to be needle prick injuries (52.5\%) which is a usual finding in many developing countries and confirms the findings of study carried out by Naghavi et al, reason being poor adherence to 
safety policies, lack of time and resources and lack of proper education about safety measures. ${ }^{8}$ Almost $50 \%$ doctors said they weren't using any preventive measures at the time, mostly $(42.1 \%)$ because of the lack of facilities in hospital or lack of time $(22 \%)$.

Second most frequent hazard recorded was workload/stress/exhaustion (42.5\%). Such a significantly high rates are consistent with studies conducted in many other countries including the Europe (Working Conditions Survey-2005) and South Asian countries (India, Sri Lanka, Bangladesh) where the high prevalence is due particularly to overpopulation and lack of resources. The increased burden on hospitals coupled with lack of resources results in increased workload hence stress and exhaustion of the doctors. The working hours of $40.5 \%$ doctors exceeded 60 hours per week which clearly is responsible for the high stress level and workload, which leads to poor on job performance and in some cases even a career change. ${ }^{9}$

Depression and anxiety was the $3^{\text {rd }}$ most frequent hazard. (30\%). This was significantly higher than study carried out by (Firth-Cozens, 2006) in U.K which found that between 10 and $20 \%$ of the doctors in U.K were suffering from depression. ${ }^{10}$ Our study however confirms findings of (Khawaja A et al 2018) who found that almost $39 \%$ family practitioners in Pakistan were suffering from anxiety and depression. ${ }^{11}$ This significantly higher percentage of doctors suffering from anxiety and depression in Pakistan may be linked to long working hours, patient overload, and poor working conditions in Pakistan. Thus, controlling the workload/stress and exhaustion can significantly decrease the occurrence of the most prevalent hazards.

Risk of mechanical and physical injuries was significantly lower compared to other countries (only $28.5 \%$ ) showing good ergonomic design of workplaces and better working environment. Other hazards include nosocomial infections (25.5\%), physical and verbal abuse (25.5\%) and workplace bullying (25\%).

$79.9 \%$ of people encountered these hazards repeatedly. Such high percentage of repeated exposure may be due to lack of facilities, education about safety measures and failure of hospital management to take necessary steps to address the problems.
The outcome of constant exposure to these hazards is in the form of decreased quality of treatment provided to the patients. When asked about the effects of these hazards, it was found that it affected the dealing with the patients in the form of lack of concentration (32\%), carelessness $(13 \%)$, lack of time given to the patient $(9 \%)$ and irritable behavior with the patient $(4 \%)$.

Education and awareness about the preventive measures is important in order to decrease the incidence of the hazards. Probably the increased rate of the hazards is due to decreased education about them. Most (38\%) of the doctors who knew said they are self-taught. There should be increased number of seminars, short courses and on job trainings etc. on the topic to encourage the use of preventive measures.

Reporting the hazards to the management and proper authorities is important too, so that proper means and methods are devised to decrease their incidence. $51.9 \%$ of the doctors mentioned having reported the hazards to the management but in $78 \%$ cases, necessary response was not given to address the problem. Such a poor response by the management towards addressing the problems may explain why almost halve of the doctors don't report incidents at workplace.

A nationwide questionnaire with 77 consultant surgeons from various specialties found out that $80 \%$ experienced pain during performing surgery, with plastic surgeons having the highest incidence in a non-statistical comparison with general surgeons, neurosurgeons, orthopedic surgeons and otolaryngologists. ${ }^{12}$ Our study found out that the highest complaint of musculoskeletal pain was found in surgeons in comparison to specialties like otolaryngology, medicine, gynecology and pediatrics.

A study by Au et al. found that out only $2.26 \%$ (19 out of 840) needle stick injuries were reported with reporting rates being low in sub-specialties. ${ }^{13}$ In 2006 , another study of 24 publications on sharps injuries found that the degree of under-reporting may reach 10 -folds. ${ }^{14}$ Our study found out that needle stick injuries was the most common $(52.5 \%)$ type of hazard encountered by doctors. Another study in this regard found that in 175 cases accidental contamination during sharps injuries in junior doctors was $54 \%$ as compared to $46 \%$ in their seniors in the same setting. ${ }^{8}$ Also a study conducted in 1990 on 221 medical and 
surgical staff found out that $74 \%$ participants received needle stick injuries at least once. Surgical team had prevalence of six times as much as medical specialty staff. ${ }^{15}$

In the year 2013, 25,630 incidents of work place violence were reported in the US. $74 \%$ of these incidents were healthcare related. ${ }^{16} \mathrm{~A}$ study in Birmingham was conducted which showed that $65 \%$ of general practitioners (GP's) suffered from abuse or violence at least once in the last year, $0.5 \%$ of whom suffered some serious injury. Another survey found that over $60 \%$ of GPs experienced some abuse or violence by patients or attendants $s$ over a 1-year period and nearly $20 \%$ reported abuse at least once monthly. ${ }^{17} \mathrm{~A}$ study in Germany, published in 2015, reported that almost half of GP's were confronted with hostile behavior, with $10 \%$ of them suffering from physical assault and/or criminal damage to property. ${ }^{18}$ A study from India reported that about $87 \%$ of violent incidents were verbal while $8.4 \%$ were physical. $^{19}$ In our study physical or verbal abuse by patients or attendants was $25.5 \%$.

Similarly a research conducted in Tamil Nadu India, $54(53 \%)$ of men and $35(48 \%)$ of women faced bullying. Significant proportions $(P<0.0001)$ of medical personnel bullied the $P G s$ and paramedical staff bullied junior doctors, more than $85(90 \%)$ of which went unreported. Workplace bullying is common among trainee doctors and usually goes unreported ${ }^{20}$

The lowest of any workplace hazard faced by healthcare professionals in our study was workplace bullying having a prevalence of $25 \%$. For another study conducted in UK, the reported prevalence of bullying was $9.7 \%$. Prevalence was found to be the highest in doctors of foundation year one and those working in Obstetrics and Gynaecology. ${ }^{21}$

In a study conducted on junior doctors in Punjab and Sindh, 417 (63.8 percent) of them reported bullying in the last year. 436 (66.7 percent) doctors had witnessed bullying of others. Consultants practiced the highest bullying (51.6 percent). Moreover, 306 (73.4 percent) participants stayed quiet about reporting bullying. ${ }^{22}$

\section{CONCLUSION}

Most common occupational hazards were found to be needle prick injury and exhaustion, and they were more prevalent among the doctors of surgery department. Consequently, doctors aren't able to perform their duties properly. Moreover, the hazards remained unreported both from doctors' and hospital administration's side.

\section{RECOMMENDATIONS}

Awareness of medical staff regarding hazards of workplace should be increased by utilizing print media and seminars. Doctors should be encouraged to come forward with the hazards they face. The administration should manage these hazards professionally. Preventive equipment should be available to medical practitioners according to their work setting. Use of disposable instruments should be encouraged. The number of patients looked after by the number of doctors should be realistic and should not overburden the doctors. Doctors should gain patients confidence and also take time off if so needed so that they can be able to provide better service in the long-term.

\section{CONFLICT OF INTEREST}

There are no conflict of interest. Limitation of the study were a relatively small sample size, being conducted in a single centre and lack of insight into how much patient care was objectively compromised due to healthcare hazards.

\section{REFERENCES}

1. Goniewicz M, Włoszczak-Szubzda A, Niemcewicz M, Witt M, Marciniak-Niemcewicz A, Jarosz MJ. Injuries caused by sharp instruments among healthcare workers--international and Polish perspectives. Ann Agric Environ Med 2012;19(3):523-7.

2. Joseph $B$, Joseph $M$. The health of the healthcare workers. Indian J Occup Environ Med 2016;20(2): 71-2.

3. Astutis. Latest HSE statistics published for 2014/2015. [Internet]. 2015 [Cited on Sep 6, $\left.2 \begin{array}{llll}2 & 0 & 2 & 0\end{array}\right]$. A va i a ble f $\mathrm{r} 0 \mathrm{~m}$ : https://www.astutis.com/news/health-and-safetystatistics

4. Karahan A, Kav S, Abbasoglu A, Dogan N. Low back pain: prevalence and associated risk factors among hospital staff. J Adv Nurs 2009;65(3):516-24.

5. Stewart WF, Ricci JA, Chee E, Morganstein D, Lipton R. Lost productive time and cost due to common pain conditions in the US workforce. JAMA 2003;290(18):2443-54.

6. National Institute for Occupation Safety and Health (NIOSH). Preventing needle-stick injuries in healthcare setting, DHHS (NIOSH) Publication No. 2000108. [Internet] 1999 [Cited on Sep 6, 2020]. A $\vee$ a i a b l e f r o m : https://www.cdc.gov/niosh/docs/2000-108/pdfs /2000-108.pdf

7. Pourhoseingholi MA, Vahedi M, Rahimzadeh M. Sample size calculation in medical studies. Gastroenterol Hepatol Bed Bench.2013;6(1):14-17. 
8. Naghavi SH Sanati KA. Accidental blood and body fluid exposure among doctors. Occup Med (Lond) 2009;59:10-16.

9. Antoniou A, Davidson M, Cooper C. Occupational stress, job satisfaction and health state in male and female junior hospital doctors in Greece. J Manag Psychol 2003;18(6):592-621.

10. Weigl M, Hornung S, Petru R, Glaser J, Angerer P. Depressive symptoms in junior doctors: a followup study on work-related determinants. Int Arch Occup Environ Health 2011;85(5):559-70.

11. Khuwaja AK, Qureshi R, Azam SI. Prevalence and factors associated with anxiety and depression among family practitioners in Karachi, Pakistan. J Pak Med Assoc 2004;54(2):45-9.

12. Soueid A OuditD Thiagarajah S Laitung $G$. The pain of surgery: pain experienced by surgeons while operating. Int J Surg 2010;8:118-20.

13. $\mathrm{Au} E$ Gossage JA Bailey SR . The reporting of needlestick injuries sustained in theatre by surgeons: are we under-reporting? J Hosp Infect 2008;70:66-70.

14. Elder A Paterson C. Sharps injuries in UK health care: a review of injury rates, viral transmission and potential efficacy of safety devices. Occup Med (Lond) 2006;56:566-74.

15. Heald AE, Ransohoff DF. Needlestick injuries among resident physicians. J Gen Intern Med 1990;5:389-93.

16. Occupational Safety and Health Administration (OSHA). Facts about Hospital Worker Safety. [Internet] 2013 [Cited on Sep 6, 2020]. Avaiable from:https://www.osha.gov/dsg/hospitals/docume nts/1.2_Factbook_508.pdf

17. Jenkins MG, Rocke LG McNicholl BP, Hughes DM. Violence and verbal abuse against staff in accident and emergency departments: A survey of consultants in the UK and the Republic of Ireland. J Accid Emerg Med 1998;15:262-5.

18. Vorderwülbecke F, Feistle M, Mehring M, Schneider A, Linde K. Aggression and violence against primary care physiciansa nationwide questionnaire survey. Dtsch Arztebl Int 2015;112(10):159-65.

19. Kumar M, Verma M, Das T, Pardeshi G, Kishore J, Padmanandan A. A Study of Workplace Violence Experienced by Doctors and Associated Risk Factors in a Tertiary Care Hospital of South Delhi, India. J Clin Diagn Res 2016;10:LC0610.

20. Bairy $\mathrm{K}$ L, Thirumalaikolundusubramanian $P$, Sivagnanam G, Saraswathi S, Sachidananda A, Shalini A. Bullying among trainee doctors in Southern India: A questionnaire study. J Postgrad Med 2007;53:87-90.

21. Gafson I, Currie J, O'Dwyer S, Woolf K, Griffin A. Attitudes towards attrition among UK trainees in obstetrics and gynaecology. Br J Hosp Med (Lond) 2017;78(6):344-8.

22. Imran N, Jawaid M, Haider I I, Masood Z. Bullying of junior doctors in Pakistan: a cross-sectional survey. Singapore Med J 2010;51(7):592-5.

DATA SHARING STATEMENT: The data that support the findings of this study are available on request from the corresponding author. The data are not publicly available due to privacy or ethical restrictions.

CONFLICT OF INTEREST: Authors declared no conflict of interest.

GRANTED SUPPORT AND FINANCIAL DISCLOSURE: Nil

\section{AUTHOR'S CONTRIBUTION}

Following authors have made substantial contributions to the manuscript as under

Farooq MU, Iqbal A:

Concept and design of study, Collection of data, statistical analysis

Shah MT, Khan S: Writing of manuscript, critical Farhan U, Misbah D: review of manuscript Analysis and interpretation of data, statistical analysis

Shazia S, Fayaz M: Data collection, bibliography

Authors agree to be accountable for all aspects of the work in ensuring that questions related to the accuracy or integrity of any part of the work are appropriately investigated and resolved. 